\title{
ADDRESSING THE GAP: ACCOUNTABILITY MECHANISMS FOR PEACEKEEPERS ACCUSED OF SEXUAL EXPLOITATION AND ABUSE
}

\author{
Jayden van Leeuwen*
}

The United Nations (UN) has been plagued by incidents of sexual exploitation and abuse by peacekeepers for a number of years. These tragedies have had major implications for the credibility of the organisation and have hindered its ability to achieve its goals. As the organisation has struggled to address this problem, a new form of accountability has evolved: direct non-legal accountability. This article examines the problem of sexual exploitation and abuse by peacekeepers, previous responses to this problem and the emergence of this new type of accountability. Direct non-legal accountability provides a viable alternative to standard conceptions of accountability in response to the situation. Although it will not solve the problem of sexual exploitation and abuse, normative improvements could be made to these mechanisms in order to better provide some accountability to the victims of this exploitation and abuse.

\section{INTRODUCTION}

United Nations peacekeepers are often inserted into some of the direst situations on the planet and have the difficult task of attempting to maintain peace and order in communities ravaged by war, famine, natural disasters and other complex circumstances. Unfortunately, despite peacekeepers occupying positions of power and trust in some of the world's most vulnerable communities, the UN has been faced with a major crisis for a number of years - peacekeepers sexually exploiting and abusing the very people that they have been sent to protect. $^{1}$

* Submitted for the LLB (Honours) Degree, Faculty of Law, Victoria University of Wellington, 2018. I would like to express thanks to my supervisor, Dr Guy Fiti Sinclair, for his truly invaluable guidance and wisdom. Special thanks also to my friends and family, and especially my number one proof-reader and supporter, Racheal van Hilten.

1 Paisley Dodds "AP Investigation: UN troops lured kids into Haiti sex ring" Associated Press (online ed, New York, 13 April 2017). 
This ongoing issue has posed a challenge to successive Secretaries-General, and the international community as a whole for many years, with numerous mechanisms designed and implemented in an attempt to provide accountability for these crimes. Many of these mechanisms can be characterised as attempting to force troop-contributing countries to exercise their exclusive criminal jurisdiction over their peacekeepers. However, this article will focus on the development of accountability mechanisms which provide for the rights and interests of victims, evaluating them against principles of accountability and victims' rights more generally, in order to assess these recent mechanisms for the accountability of peacekeepers who commit sexual exploitation or abuse. Particular attention will be paid to the Secretary-General's 2017 Report on "Special measures for protection from sexual exploitation and abuse" (the 2017 Report), and the mechanisms outlined within it. ${ }^{2}$ Ultimately, there is still a critical lack of legal accountability, with mechanisms increasingly focused on providing a form of direct non-legal accountability through creating a sense of moral retribution and acknowledgement of suffering. In particular, these mechanisms can be seen to provide for the rights and interests of victims in a manner consistent with those outlined in the Declaration of Basic Principles of Justice for Victims of Crime and Abuse of Power. ${ }^{3}$ Although these are positive steps, the article will build on this analysis to also engage in discussion as to how this accountability could be improved, paying particular attention to initiatives such as victim impact statements and restorative justice. This new direct non-legal accountability is not a silver bullet to solve the pervasive issue of sexual exploitation and abuse, but it is an important step in providing some form of vindication for victims.

The key contention of this article is that the approach outlined in the Secretary-General's 2017 Report offers a viable alternative of accountability for victims of sexual exploitation and abuse at the hands of UN peacekeepers, and, with alterations, could fill the current gap created by the lack of legal accountability. In Part II, this article will outline the scope of the problem of peacekeepers committing sexual exploitation and abuse while on missions, before exploring the concept of accountability and some of the past solutions that have been proposed and implemented in Part III. While Part IV will discuss the new approach to the issue provided in the Secretary-General's 2017 Report, Part V will analyse this new approach and discuss potential improvements that could be made in order to provide greater accountability to victims of sexual exploitation and abuse.

\section{PROBLEM}

In order to be able to engage in discussion and analysis of the new approach to the accountability of peacekeepers who commit sexual exploitation and abuse while on mission, it is necessary to first

2 Special measures for protection from sexual exploitation and abuse: a new approach-Report of the Secretary General UN Doc A/71/818 (28 February 2017).

3 Declaration of Basic Principles of Justice for Victims of Crime and Abuse of Power GA Res 40/34 (1985). 
identify the scope of the problem. This part of the article thereby outlines the historical and contemporary manifestations of the issue.

\section{A What is Peacekeeping?}

Peacekeeping is a function of the UN which is not explicitly provided for in its Charter, but has developed gradually over time. ${ }^{4}$ Following the identification of a situation where peacekeepers would be beneficial, the authorisation for a peacekeeping operation will usually be a Security Council resolution, drawing generally on the powers vested in the Council by Chapters VI and VII of the UN Charter. ${ }^{5}$ This is followed by a series of agreements between troop-contributing countries, the host country and various branches of the UN, alongside the establishment of the command structure and support apparatus for the mission. ${ }^{6}$ Ideally, the mission will be founded on the consent of the host state in order to maximise cooperation and local engagement, but this is not strictly necessary due to the binding authority of the Security Council's Chapter VII powers. ${ }^{7}$ As such, it is entirely possible for a mission to face a hostile reception in the host state.

Peacekeeping missions vary in their size and composition. They can be short-term arrangements designed to provide interim stability, or longer running operations more heavily focused on issues such as peacebuilding and ceasefire management. Since 1948, there have been 71 peacekeeping missions, of which 14 are still active at the time of writing. ${ }^{8}$ Although the concept of peacekeeping has faced criticism for decades over issues such as cost, "mission creep" and measures of tangible success, in more recent years the UN has been plagued by the ongoing challenge posed by peacekeepers perpetrating sexual exploitation and abuse while on missions.

\section{B Sexual Exploitation and Abuse}

The issue of sexual exploitation and abuse in peacekeeping missions rose to global prominence in the early 2000s following allegations of widespread instances of exploitation and abuse by peacekeepers within the UN Organisation Mission in the Democratic Republic of the Congo (MONUSCO). Between January 2004 and December 2005, 278 peacekeeping personnel were investigated by the Office of Internal Oversight Services (OIOS) for alleged instances of sexual exploitation and abuse, with 122 military personnel and 16 police officers repatriated. ${ }^{9}$ The scandal

4 Shayna Ann Giles "Criminal Prosecution of UN Peacekeepers: When Defenders of Peace Incite Further Conflict Through Their Own Misconduct" (2017) 33 Am U Int'l L Rev 147 at 154.

5 At 154 .

6 At 156.

7 At 155 .

8 United Nations Peacekeeping "Where We Operate" <https://peacekeeping.un.org>.

9 Ray Murphy "An Assessment of UN Efforts to Address Sexual Misconduct by Peacekeeping Personnel" (2006) 13 Int'l Peacekeeping 531 at 532. 
was widely reported by international media, and the UN faced immense public scrutiny for the widespread nature of the offending throughout the mission. ${ }^{10}$ Although MONUSCO was not the first peacekeeping mission to be marred by allegations of sexual exploitation and abuse by peacekeepers, the scale of the offending meant the situation became a major political issue, unlike incidents that were more readily brushed aside such as those in Mozambique, Somalia, East Timor and Bosnia and Herzegovina during the 1990s. ${ }^{11}$

Despite a series of inquiries and numerous new initiatives being implemented in the years following the MONUSCO scandal, peacekeeping missions have continued to see allegations of sexual exploitation and abuse in recent years. For over four years in Haiti following the 2010 earthquake, peacekeepers from the UN Stabilization Mission in Haiti (MINUSTAH) operated sex rings involving girls as young as twelve years old. ${ }^{12}$ These sex rings involved not only the sexual abuse of young girls, but also the exploitation of the peacekeepers' positions of authority to manipulate the victims into silence. ${ }^{13}$ Peacekeepers in the UN Multidimensional Integrated Stabilization Mission in the Central African Republic (MINUSCA) were accused of numerous instances of rape, with the allegations being brushed aside by MINUSCA officials and only coming to light following the leaking of information by a UN official. ${ }^{14}$ These are just two examples of what is unfortunately a pervasive issue within UN peacekeeping missions.

According to UN statistics, allegations of sexual exploitation and abuse by peacekeepers had generally been trending downwards since comprehensive data collection began in 2007, with the number of allegations falling from 127 in the first year of record keeping to 52 in 2014. ${ }^{15}$ Despite these decreasing statistics, 2015 and 2016 saw the numbers climb again, with 69 and 104 allegations respectively. ${ }^{16}$ Sixty-two allegations were made in 2017, and as at the time of writing, 54 allegations were made in 2018, and one allegation had been made in 2019. ${ }^{17}$ The fluctuation of these numbers demonstrates the complex challenge of combating this pervasive problem, with responses to date having mixed success. Academics such as Kate Grady question the accuracy of these statistics, arguing that it is likely that the statistics do not accurately represent the true scale of the sexual

10 Joseph Loconte "The UN Sex Scandal" The Weekly Standard (online ed, Washington DC, 3 January 2005).

11 Murphy, above n 9, at 531.

12 Dodds, above n 1.

13 Dodds, above n 1.

14 Sandra Laville "UN troops 'abused at least eight women and girls' in Central African Republic" The Guardian (online ed, London, 4 February 2016).

15 Conduct in UN Field Missions "Sexual Exploitation and Abuse" <https://conduct.unmissions.org>.

16 "Sexual Exploitation and Abuse", above n 15.

17 "Sexual Exploitation and Abuse", above n 15. 
exploitation and abuse that is carried out by peacekeepers. ${ }^{18}$ Grady reasons that this is likely due to the potential under-reporting of incidents because of factors such as fear and intimidation. ${ }^{19}$ The exploitative nature of many of the interactions is itself a potential barrier to reporting due to the misuse of positions of trust and authority to manipulate victims into keeping their abuse hidden.

Regardless of whether these statistics are accurate, they indicate that the UN has a systemic issue. Any instance of sexual exploitation or abuse by a peacekeeper undermines the credibility of the UN in the very communities it is trying to protect, having untold counterproductive results. At a more fundamental level, it is an abhorrent violation of the rights of the victims, and can in no way be justified, ignored, or condoned. This is reflected in the UN's "zero tolerance" policy for sexual exploitation and abuse by its staff, including peacekeepers. All field personnel on peacekeeping missions are given a "no-excuses" card on deployment which outlines the UN's zero tolerance policy, meaning there is no issue of a lack of understanding - but despite this, these despicable acts continue to occur. ${ }^{20}$

\section{ADDRESSING THE PROBLEM - PAST RESPONSES}

Understanding the past solutions that have been proposed and implemented is crucial in order to discuss the new approach to accountability. Part III therefore seeks to survey previous responses to the issue and conceptualisations of accountability in order to provide a grounding from which to explore the new approach.

\section{A The Concept of Accountability}

Accountability can be defined in a number of differing ways, depending on who is being held accountable, and who that accountability is to. According to the Oxford English Dictionary, accountability is the "fact or condition of being accountable; responsibility". ${ }^{21}$ In a practical sense, it involves the perpetrator being held to account for their actions. Accountability is critically important for the UN, especially in relation to its peacekeeping missions. Accountability enhances legitimacy and public trust in the organisation and those carrying out its missions, and without this legitimacy it is difficult for the goals of a peacekeeping mission to be achieved. ${ }^{22}$ Where trust is broken in this way, the symbol of the UN becomes one of oppression and abuse, not aid and protection. It is therefore important that individuals do not believe peacekeepers can act with impunity.

18 Kate Grady "Sex, Statistics, Peacekeepers and Power: UN Data on Sexual Exploitation and Abuse and the Quest for Legal Reform" (2016) 79 MLR 931 at 936-937.

19 At 936-937.

20 Special measures for protection from sexual exploitation and abuse: a new approach-Report of the Secretary General, above n 2, at 32.

21 English: Oxford Living Dictionaries "Accountability"<https://en.oxforddictionaries.com>.

22 Devika Hovell "Due Process in the United Nations" (2016) 110 AJIL 1 at 46-47. 
Ruth Grant and Robert Keohane characterise accountability into seven different types: hierarchical, supervisory, fiscal, legal, market, peer and public reputational. ${ }^{23}$ This formula of analysis can be used to describe mechanisms applicable to peacekeepers who perpetrate sexual exploitation and abuse. The main types of accountability that these individuals are likely to be subject to are hierarchical and legal; hierarchical accountability involves peacekeepers being held to account by their superiors within the applicable disciplinary processes, while legal accountability concerns their liability for legal consequences. ${ }^{24}$ However, not all of the mechanisms that the UN has implemented fit cleanly within these categories, and can instead be characterised by their apparent effect of providing some form of non-legal accountability to the victims themselves, in a moral, cathartic sense - the idea of knowing their attacker has faced consequences for their actions, and offering a degree of closure. The measures outlined in the Secretary-General's 2017 Report broadly fit within this characterisation in that they seek to increase support for victims, acknowledge their suffering and provide a sense of moral vindication and closure for the victim. ${ }^{25}$

\section{$B$ The Barrier of the Status Quo}

A key element of the UN's response to the issue has been attempting to hold perpetrators accountable for their actions, but a major barrier remains in that peacekeepers are under the jurisdiction of their troop-contributing country. ${ }^{26}$ This means that the troop-contributing country retains the exclusive ability to prosecute and punish their peacekeepers. At the heart of this arrangement is the concept of state sovereignty, and accordingly the troop-contributing country retains active personality jurisdiction of its troops at the expense of the host country and the UN. ${ }^{27}$ This is codified in the status of forces agreement (SOFA), which establishes the necessary arrangements for peacekeeping missions between the UN and the host country. All peacekeeping missions utilise the model SOFA of 1990, cl 47(b) of which states: ${ }^{28}$

Military members of the military component of the United Nations peace-keeping operation shall be subject to the exclusive jurisdiction of their respective participating States in respect of any criminal offences which may be committed by them in [the host country].

23 Ruth W Grant and Robert O Keohane "Accountability and Abuses of Power in World Politics" (2005) 99 APSR 29 at 36.

24 At 36-37.

25 Special measures for protection from sexual exploitation and abuse: a new approach - Report of the Secretary General, above n 2, at 6-8.

26 Melanie O'Brien Criminalising Peacekeepers: Modernising National Approaches to Sexual Exploitation and Abuse (Palgrave Macmillan, Basingstoke (UK), 2017) at 33.

27 At 33.

28 Model status of forces agreement for peacekeeping operations: Report of the Secretary-General UN Doc A/45/594 (9 October 1990) at [47(b)]. 
This arrangement is therefore standard policy and applies to all criminal offences carried out by peacekeepers while on a mission, regardless of whether they occurred in the course of their official duties. In this sense, peacekeepers have absolute immunity from the jurisdiction of host country judicial systems, as opposed to the more standard functional immunity granted to general UN employees. ${ }^{29}$ In line with this default position, allegations of sexual exploitation and abuse can still be investigated by the OIOS and result in mandatory repatriation of the alleged offender, but any form of legal accountability lies with the troop-contributing country. ${ }^{30}$

Moreover, this creates a significant barrier to meaningful accountability of peacekeepers who perpetrate sexual exploitation and abuse. There is a pervasive and ingrained "boys club" mentality within peacekeeping operations which stymies investigations when peacekeepers "close ranks", undermining the efforts of UN investigators. ${ }^{31}$ Because the troop-contributing country retains jurisdiction, the most severe outcome of an OIOS investigation is the repatriation of the peacekeeper, with the troop-contributing country remaining responsible for any criminal or administrative punishment. If a peacekeeper is repatriated, there is still a question as to whether the troopcontributing country will carry out its own investigation, and if it does, whether there will be any serious consequences for the offence. Despite pressure from the UN itself, as well as from civil society actors and the public, troop-contributing countries continue to be reluctant to carry out their own investigations, or pursue prosecutions against repatriated peacekeepers. ${ }^{32}$ Most investigations and punishments that do occur are usually within the military justice system of the troop-contributing country and can result in almost tokenistic accountability; a large number of perpetrators are sentenced to administrative or disciplinary measures, with minimal imprisonment or other serious punishments. ${ }^{33}$

Data compiled by the Department of Peacekeeping Operations reveals that those perpetrators who are investigated and prosecuted all too often receive minimal punishment for their crimes. This data on allegations of sexual exploitation and abuse details the outcomes of troop-contributing country investigations. For example:

29 Anthony J Miller "Legal Aspects of Stopping Sexual Exploitation and Abuse in UN Peacekeeping Operations" (2006) 39 Cornell Int'l LJ 71 at 86 and 90.

30 Elizabeth F Defeis "UN Peacekeepers and Sexual Abuse and Exploitation: An End to Impunity" (2008) 7 Wash U Global Stud L Rev 185 at 197.

31 O'Brien, above n 26, at 8.

32 Sarah Smith "Accountability and sexual exploitation and abuse in peace operations" (2017) 71 Aust J Int'l Aff 405 at 408.

33 Marco Odello and Róisín Burke "Between immunity and impunity: peacekeeping and sexual abuses and violence" (2016) 20 The International Journal of Human Rights 839 at 839. 
(a) a Gabonese peacekeeper was found to have raped a child in 2016 and was sentenced to only 45 days in prison, while retaining his position in the army;

(b) a Mauritanian peacekeeper was found to have raped a child in 2017 and although dismissed from the army, was only sentenced to 60 days in prison; and

(c) a Moroccan peacekeeper was found to have committed sexual assault in 2015 and was sentenced to only 40 days in prison, while retaining his position in the army. ${ }^{34}$

This data also indicates that there is often little distinction between different types of sexual exploitation and abuse when it comes to punishment.

It is also common for peacekeepers who have been found to have carried out offences such as these to go through long periods of time in which no punishment is handed down, despite a finding of guilt. For example, a sexual assault perpetrated by a peacekeeper from the Democratic Republic of the Congo in 2015 is still pending action, as is a substantiated rape of a child by a Tanzanian peacekeeper in 2016. ${ }^{35}$ This sort of "limbo" contributes to the sense of impunity for these crimes, and these instances represent an alarming reality when it comes to the accountability of peacekeepers for sexual exploitation and abuse. Because troop-contributing countries retain jurisdiction, there is little ability for the UN to take meaningful action, and the response of troop-contributing countries to repatriated peacekeepers is often lacklustre, as evidenced above. ${ }^{36}$ With the SOFA forming a key component of all peacekeeping missions, and state consent underlying the existence of those missions, the UN has struggled to find methods which create meaningful accountability for those who are subjected to sexual exploitation and abuse by peacekeepers.

\section{Attempts to Circumvent the Status of Forces Agreement Issue}

The legal position created by the SOFAs has forced the UN to pursue alternative means through which to hold peacekeepers to account due to the limitations on its hierarchical accountability and its inability to provide legal accountability. Mechanisms have instead largely fallen within two categories: those which seek to force legal accountability, and those which look to provide non-legal accountability directly to the victims. Following the widespread abuse in MONUSCO during the early 2000s, Secretary-General Kofi Annan ordered an inquiry into sexual exploitation and abuse in UN peacekeeping missions. ${ }^{37}$ This report (the Zeid Report) was the first major investigation into the issue, and involved a comprehensive review of the UN's response to the MONUSCO allegations. The Zeid Report noted the practical barrier to achieving legal accountability posed by the troop-contributing country retaining jurisdiction, and recommended strong hierarchical accountability in its place,

34 "Sexual Exploitation and Abuse", above n 15.

35 "Sexual Exploitation and Abuse", above n 15.

36 "Sexual Exploitation and Abuse", above n 15.

37 Miller, above n 29, at 73. 
alongside the Secretary-General obtaining "formal assurances" 38 from troop-contributing countries that criminal jurisdiction will be exercised. ${ }^{39}$ Despite this pressure for accountability, many troopcontributing countries still neglect to fully exercise their jurisdiction, as evidenced above.

When it comes to measures which seek to provide direct support to victims and acknowledge their suffering, there has been a focus on the provision of financial assistance to aid in recovery. In 2007, the General Assembly adopted the Comprehensive Strategy on Assistance and Support to Victims of Sexual Exploitation and Abuse by United Nations Staff and Associated Personnel, which outlined the support victims should receive following allegations, and provided for minimum standards of assistance in areas such as medical care, legal services and psychological support. ${ }^{40}$ In March 2016, the Secretary-General established the Trust Fund in Support of Victims of Sexual Exploitation and Abuse (the Trust Fund), a fund which provides financial support to victims in order to aid their recovery, but does not provide compensation. ${ }^{41}$ Furthermore, the General Assembly agreed in June 2016 to transfer payments withheld from peacekeepers in instances of substantiated sexual exploitation and abuse to the Trust Fund in order to boost its funding. ${ }^{42}$

There have also been a number of key mechanisms employed by the UN that have sought to force troop-contributing countries to exercise criminal jurisdiction. In his 2016 report on the issue, Secretary-General Ban Ki-moon publicly disclosed for the first time the nationalities of those peacekeepers accused of sexual exploitation and abuse in the previous year. ${ }^{43}$ Under Resolution 2272 the Security Council authorised the Secretary-General to repatriate entire peacekeeping contingents from certain member states when there are allegations of sexual exploitation or abuse, and to decline further deployment of troops from that country in the future. ${ }^{44}$ Measures such as these seek to pressure troop-contributing countries to investigate allegations and adequately punish perpetrators by publicly disclosing the fact that their troops have been alleged to have committed these crimes, and preventing the use of troops from that member state in the future because of their failure to hold perpetrators to

38 A comprehensive strategy to eliminate future sexual exploitation and abuse in United Nations peacekeeping operations UN Doc A/59/710 (24 March 2005) at 6.

39 At 5.

40 United Nations Comprehensive Strategy on Assistance and Support to Victims of Sexual Exploitation and Abuse by United Nations Staff and Related Personnel GA Res 62/214 (2008).

41 Conduct in UN Field Missions "Trust Fund on Victim Assistance" < https://conduct.unmissions.org>.

42 Cross-cutting issues GA Res 70/286 (2016).

43 Special measures for protection from sexual exploitation and sexual abuse: Report of the Secretary General UN Doc A/70/729 (16 February 2016) at 9 and 10.

44 SC Res 2272 (2016). 
account. ${ }^{45}$ Although these measures do not guarantee that there will be any form of legal accountability, in theory they do at least increase the likelihood that it will occur.

Nevertheless, these mechanisms have been criticised for failing to eliminate the problem of sexual exploitation and abuse by peacekeepers. Sarah Smith has criticised the fact that these mechanisms result in the perpetrator being removed from the site of their offending, which although prevents future exploitation or abuse in a peacekeeping capacity, does little to punish the perpetrator, provide justice to the victim, or increase the UN's legitimacy within the harmed community. ${ }^{46}$ Róisín Burke has argued that in order to better ensure the accountability of those accused of sexual exploitation and abuse, the Model SOFA should be rewritten in line with the agreement utilised by NATO, which essentially provides peacekeepers and soldiers in foreign states functional immunity in relation to their duties only, as opposed to absolute immunity, as well as concurrent jurisdiction in cases of offending in the course of official duties. ${ }^{47}$ Others such as Andrew Ladley have instead reasoned that the establishment of international individual criminal responsibility or a UN ombudsperson could help to ensure that perpetrators of sexual exploitation and abuse are held to account by shifting responsibility for investigation and punishment away from troop-contributing countries. ${ }^{48}$

Many of these scholars have focused on the perceived shortcomings of hierarchical accountability and the lack of guaranteed legal accountability in instances of sexual exploitation and abuse, with the fact that the troop-contributing country retains criminal jurisdiction being at the heart of these criticisms. It is however a political reality that is unlikely to change, due to the concerns of troopcontributing countries around the procedural safeguards and human rights standards present in the court systems of some host countries. ${ }^{49}$ As such, it is instead important to consider the extent to which the UN's alternative mechanisms have been able to provide accountability beyond the conventional considerations of legal and hierarchical accountability. In particular, the provision of accountability to the victims themselves has seemingly become a more central aim of the alternative mechanisms suggested by successive Secretaries-General in their annual reports since 2004. This accountability has increasingly been concerned with the provision of tangible support and a sense of moral retribution

45 Rembert Boom "Introductory Note to United Nations Security Council Resolution 2272 and Secretary General Report on Special Measures for Protection From Sexual Exploitation and Sexual Abuse" (2016) 55 ILM 756 at 756.

46 Smith, above n 32, at 406-407.

47 Roísín Burke "Central African Republic Peacekeeper Sexual Crimes, Institutional Failings: Addressing the Accountability Gap" (2016) 14 NZJPIL 97 at 116

48 Andrew Ladley "Peacekeeper Abuse, Immunity and Impunity: The Need for Effective Criminal and Civil Accountability on International Peace Operations" (2005) 1 Politics and Ethics Review 81 at 87-88.

49 Odello and Burke, above n 33, 846-847. 
for the victim in the place of conventional accountability through criminal sanctions. In many senses, this is the UN doing what it can, with the limited powers it has, within the existing framework.

\section{A NEW AND MORE COMPREHENSIVE APPROACH?}

Having explored the scope of the problem and previous responses by the UN, this part of the article discusses and analyses the new approach to accountability for sexual exploitation and abuse by peacekeepers found in the Secretary-General's 2017 Report.

At the beginning of every year since 2004, the Secretary-General has released a report into sexual exploitation and abuse throughout the UN system. Within these reports, allegations from the previous calendar year are outlined in detail, new mechanisms to tackle the issue are often introduced and it is also commonplace for the effectiveness of existing mechanisms to be discussed. In his first report as Secretary General, the 2017 Report, Antonio Guterres outlined what he termed a "new approach" to addressing sexual exploitation and abuse by peacekeepers and providing for the accountability of perpetrators. ${ }^{50}$ Two major mechanisms recommended in that report were the appointment of a Victims' Rights Advocate (VRA), and that member states should authorise the withholding of payments if troop-contributing countries fail to carry out or complete investigations in a timely manner, with these amounts then transferred to the Trust Fund. ${ }^{51}$ The VRA is a mechanism that seeks to provide direct non-legal accountability to victims, whereas the recommended withholding of payments is a measure that seeks to force troop-contributing countries to exercise their criminal jurisdiction. Whereas the VRA, as a member of the Secretariat, was appointable by the SecretaryGeneral himself, the withholding of payments requires the authorisation of the General Assembly. However, this has not yet occured, and the recommendation therefore remains exactly that.

\section{A The Victims' Rights Advocate}

The VRA is a system-wide official with the overarching goal of leading an "integrated, strategic response to victim assistance", 52 to "strengthen the support that the United Nations gives to victims of sexual exploitation and abuse by providing them with adequate protection, appropriate assistance, and reliable recourse to justice." 53 In order to achieve this, the VRA works with: ${ }^{54}$

50 Special measures for protection from sexual exploitation and abuse: a new approach-Report of the Secretary General, above n 2, at 1.

51 At 9-10.

52 United Nations "Terms of Reference - Victims' Rights Advocate" <www.un.org> at 1.

53 United Nations "Victims' Rights Advocate" Preventing Sexual Exploitation and Abuse <www.un.org>.

54 United Nations "Terms of Reference", above n 52, at 1. 
... government institutions, civil society, and national legal and human rights organizations to build networks of support and to help ensure that the full effect of local laws, including remedies for victims, are brought to bear.

Practically, this goal manifests itself in the provision of advice and support to UN entities, engaging with member states and civil society, and communicating with and providing support to victims. ${ }^{55}$ Respected human rights lawyer Jane Connors was appointed as the first VRA on 23 August 2017, and continues to hold the position today. ${ }^{56}$ Alongside Ms Connors, field based advocates have also been appointed to certain missions with high rates of sexual exploitation and abuse to provide support to victims more readily. ${ }^{57}$

The VRA is an example of a mechanism which seeks to facilitate the provision of direct non-legal accountability to the victim. Although Ms Connors is unable to forcefully pursue the legal accountability of the perpetrator, she and her staff are able to provide direct and tangible support to victims. In Ms Connors' own words, her role is to: ${ }^{58}$

... give a voice to victims ... to ensure that there is capacity to collect evidence, so that there can be a proper investigation of the events and so that possibly there could be accountability ... making sure that the process takes into account the rights and entitlements of the victims, to translate the victim into a survivor.

The role seeks to place victims at the centre of the post-abuse process, and to provide for their interests. Working alongside victims to acknowledge their suffering, ensuring that they receive the support they need and facilitating the investigation of the offending helps to increase the faith of victims and their communities in the UN, and therefore enhance the legitimacy of the organisation. Although this is not conventional legal accountability, the VRA is a mechanism that can be seen to provide a sense of moral vindication for the victim, providing for their interests and cathartically acknowledging that some wrong has been done for which support must now be given. This fits more within the form of direct accountability to the victims themselves, and although not guaranteeing legal accountability or even an investigative process, it still works to provide victims with some degree of closure.

55 At $1-2$

56 "Victims' Rights Advocate", above n 53.

57 United Nations "Field Victims' Rights Advocates" Preventing Sexual Exploitation and Abuse < www.un.org>.

58 United Nations "'This role is to give a voice to the victims', tells Jane Connors" (3 November 2017) YouTube $<$ www.youtube.com>. 


\section{B The Trust Fund Changes}

The Trust Fund seeks to address service gaps in the provision of support and assistance to complainants, victims and children born of sexual exploitation and abuse. ${ }^{59}$ Its primary source of funding is contributions from member states, but the buy-in has been relatively minimal; to date, contributions have come from only nineteen member states, including Australia, Bhutan, Cyprus, India, Japan and Norway. ${ }^{60}$ As noted above, the Trust Fund now receives payments witheld from peacekeepers against whom allegations have been substantiated. Although this may increase the funds available for disbursement from the Trust Fund, it is still primarily dependent on voluntary contributions. ${ }^{61}$

In his 2017 Report, the Secretary-General called on member states to authorise the withholding of payments due to peacekeepers accused of sexual exploitation and abuse and to transfer those payments to the Trust Fund when troop-contributing countries fail to carry out or complete investigations into the allegations in a timely manner. ${ }^{62}$ This will require the authorisation of the General Assembly, but at the time of writing, this has not yet been given. In proposing this mechanism, the Secretary-General sought to apply further pressure on troop-contributing countries to exercise their exclusive criminal jurisdiction to hold perpetrators legally accountable. This mechanism could also help to address the issue of investigations taking excessively long amounts of time, or undue delays in the handing down of punishments, by giving rise to repercussions for doing so.

Mechanisms such as these are not intended to create legal or hierarchical accountability. These types of accountability, especially legal, are often lauded as being crucial in order to provide justice for the victims of sexual exploitation and abuse, and scholars and commentators have therefore frequently focused their work on the need for a change to the status quo in order to provide greater legal accountability. ${ }^{63}$ The actions taken by the Secretary-General have been criticised as being inadequate, piecemeal gestures that do not create meaningful accountability for victims. ${ }^{64}$ However, to assess these measures solely on the basis of whether a traditional definition of accountability is met misses the very point of these mechanisms.

59 "Trust Fund on Victim Assistance", above n 41.

60 United Nations "Trust Fund in Support of Victims of Sexual Exploitation and Abuse" Preventing Sexual Exploitation and Abuse <www.un.org $>$.

61 "Trust Fund on Victim Assistance", above n 41.

62 Special measures for protection from sexual exploitation and abuse: a new approach-Report of the Secretary General, above n 2, at 9-10.

63 Burke, above n 47, at 116; and Ladley, above n 48, at 87-88.

64 Smith, above n 32, at 406-407. 
The VRA is not designed to provide legal accountability. Ms Connors does not have the power to investigate or sanction peacekeepers, so criticising such a mechanism for its failure to provide a type of accountability it was never meant to, is counterproductive. Similarly, measures such as transferring withheld payments to the Trust Fund do no more than apply pressure on troop-contributing countries to investigate allegations; they do not seek to guarantee legal accountability, because that is something they fundamentally cannot provide. The foundation of the UN system is ultimately state consent, so unless member states decide to reframe the Model SOFA, provide for some form of international criminal responsibility, or authorise further action by the Secretariat, the ability of the SecretaryGeneral to propose measures that fit within the traditional characterisation of accountability will continue to be naturally limited. Instead of attempting to hold these measures to a standard they can never meet, it is more productive to consider the extent to which they provide a different form of accountability - namely to the victims themselves.

\section{ANALYSIS AND PROPOSALS FOR IMPROVEMENT}

In its analysis of the "new approach", Part V employs The Declaration of Basic Principles of Justice for Victims of Crime and Abuse of Power as an analytical tool to interpret the new approach, and proposes potential improvements in order to provide greater accountability for victims of sexual exploitation and abuse. This discussion aims to highlight potential developments that could occur without displacing the legal status quo, thereby maintaining state sovereignty while still seeking to provide some level of accountability to victims.

\section{A Declaration of Basic Principles of Justice for Victims of Crime and Abuse of Power}

In 1985, the General Assembly adopted the Declaration of Basic Principles of Justice for Victims of Crime and Abuse of Power (the Declaration). ${ }^{65}$ In the Declaration, the General Assembly outlined minimum standards for criminal justice, victims' rights and the adequate provision of assistance after crime has occurred. ${ }^{66}$ Clauses $14-17$ outline the support and assistance which victims should receive in order to aid their recovery, and calls for the provision of "the necessary material, medical, psychological and social assistance" in order to support victims. ${ }^{67}$ The Declaration also emphasises the importance of victims being supported throughout any judicial process: being made aware of their rights and informed of the process, as well as the avoidance of unnecessary delay in the disposition of their case. ${ }^{68}$

65 Declaration of Basic Principles of Justice for Victims of Crime and Abuse of Power, above n 3.

66 Declaration of Basic Principles of Justice for Victims of Crime and Abuse of Power, above n 3.

67 At [14].

68 At [6]. 
Although primarily outlining appropriate minimum standards for domestic criminal justice systems and victims' rights mechanisms, the Declaration can be a useful analytical tool through which to view the efforts of the Secretary-General to tackle sexual exploitation and abuse. The mechanisms outlined in the 2017 Report do not fulfil all of the standards outlined in the Declaration, but they do take significant steps in the provision of non-legal accountability to victims by providing for their rights and interests in ways similar to those prescribed in the Declaration.

As outlined above, the VRA offers practical support to victims of sexual exploitation and abuse by ensuring that support is provided to aid them in their recovery, both by utilising disbursements from the Trust Fund but also through connecting victims with local and national support services. ${ }^{69}$ In this sense, the VRA is a mechanism which provides the kind of support described in cls 14-17 of the Declaration. In doing so, the VRA offers valuable support to help victims recover from their sexual exploitation or abuse, and transform them from a victim to a survivor.

The work of both the VRA and her team of field-based advocates informs victims of their rights, ensures that they are aware of any investigative process that is occurring and actively supports them through that process. Not only does this work align with the minimum standards laid down in the Declaration, but it also acknowledges the suffering of the victims and allows them to understand the process through which they may be proceeding. The suggested changes to the Trust Fund around withheld payments aim to force a greater incidence of investigation, which in turn helps create the conditions for the VRA to perform this aspect of her role. Regardless of whether an investigative process is engaged or not, the VRA is able to provide support and assistance to victims. ${ }^{70}$ This offers a valuable acknowledgement of their suffering: the UN recognises their experience, and although technically does not provide compensation, is willing to offer support in their recovery. In and of itself, this can be seen as a vindication of the victims' suffering - a form of non-legal moral accountability to them directly.

These mechanisms have increased the accountability of peacekeepers accused of sexual exploitation and abuse, but in a non-legal format. Although there are potential benefits arising out of a criminal justice process, ${ }^{71}$ these alternative mechanisms that seek to provide for the rights and interests of victims should not be cast aside as ineffectual or pointless. Working within the framework that exists due to the political reality of the UN, it is important to consider how these mechanisms could be further improved to better provide this kind of non-legal accountability directly to victims. Although mechanisms such as the VRA and the proposed Trust Fund changes are important steps to

69 United Nations "Terms of Reference", above n 52.

70 United Nations "The Role of the Victim Rights Advocate" Preventing Sexual Exploitation and Abuse $<$ www.un.org $>$.

71 Rebecca Campbell "The Psychological Impact of Rape Victims' Experiences With the Legal, Medical and Mental Health Systems" (2008) 63 American Psychologist 702 at 705. 
providing some form of accountability to the victims of sexual exploitation and abuse, there are a number of key changes that could be made in order to strengthen these mechanisms and improve their effectiveness. It might not be possible to provide any guarantee of legal accountability, but it is feasible that the rights and interests of victims could be further provided for.

\section{B Victim Impact Statements and Attendance at Criminal Trials}

Crimes of sexual exploitation and abuse can leave victims with long lasting emotional and psychological conditions alongside physical injuries and trauma. In many instances, the mental trauma caused by sexual exploitation and abuse can be the more detrimental form of injury to victims. ${ }^{72}$ In particular, victims often suffer from conditions such as post-traumatic stress disorder, depression, panic disorders, and in some cases, suicidal tendencies. ${ }^{73}$ Although not all victims will necessarily suffer these psychological consequences, for those who do, the aftermath continues long after their abuse and exploitation. Some survivors have stated that an important part of the healing process can be confronting their abuser, having a chance to share their experience and help their abuser to understand the damage their actions have caused. ${ }^{74}$ Critically, these opportunities are about "allowing them [victims] to come to terms with their experiences by facing their attacker and confronting perpetrators with the damage that they have caused". ${ }^{75}$

Often, a victim faces their abuser within a criminal justice process, but this is because it is simply the mechanism through which states most frequently deal with sexual exploitation and abuse. Although a criminal trial has the potential to result in tangible legal accountability through a sentence, the greater cathartic value for survivors often comes from their ability to exert some level of control over the process by sharing their experiences, obtaining justice and facing their abuser. ${ }^{76}$ Moreover, the recognition of their suffering and the legitimisation of their need for assistance and support, through both confronting their abuser and also sharing their experience, has positive effects, especially in relation to reducing survivors' guilt and negative societal responses. ${ }^{77}$ Not all survivors will want to engage in such a process, and in those instances, it is important to recognise the autonomy of these individuals. But for those who want to face their abuser and have an opportunity to engage in this kind of process, research indicates that doing so has a greater positive outcome in relation to long term

72 Jim Parsons and Tiffany Bergin "The Impact of Criminal Justice Involvement on Victims' Mental Health" (2010) 23 Journal of Traumatic Stress 182 at 182.

73 At 182 .

74 At 182 and 186.

75 At 186.

76 Campbell, above n 71, at 705 .

77 Parsons and Bergin, above n 72, at 186; and Campbell, above n 71, at 705. 
psychological and emotional health than avoidance strategies. ${ }^{78}$ There are risks associated with engaging in a criminal justice process, especially in relation to secondary victimisation and negative attitudes within the system itself, ${ }^{79}$ but addressing these concerns is beyond the scope of this article.

Overall, the opportunity to confront their abuser and receive some form of cathartic closure is a form of direct accountability to the victim because there is an element of moral retribution, a chance for the victim to look their abuser in the eye and hold them accountable directly to themselves. Although not within conventional conceptualisations of accountability such as that of Grant and Keohane, this direct accountability supports the victim in their recovery, and helps to provide closure. The research outlined above indicates that this form of accountability can be crucial to victims coming to terms with their experiences and recovering from the psychological and emotional damage of their abuse.

As some victims have been shown to recover from their abuse in a more positive way by having the opportunity to confront their abuser and share their experiences, this is an area that could be strengthened within the context of sexual exploitation and abuse by peacekeepers. Under the status quo, peacekeepers who have allegations against them substantiated by OIOS investigators are frequently repatriated to their troop-contributing country. ${ }^{80}$ Although this is ultimately the UN exercising its powers of hierarchical accountability to their fullest extent, the peacekeeper is removed from the community in which they offended. This poses an immediate barrier to victims being able to face their abusers.

In order for victims to be able to confront their abusers, either the perpetrator needs to remain in the host country, or the victim needs the opportunity to take part in any proceedings that may occur back in the troop-contributing country. Both of these options were explored in the 2017 Report. Guterres called on member states to revise the terms of reference of the Trust Fund in order to permit direct assistance payments to allow victims to attend criminal justice proceedings in troopcontributing countries, or to hold onsite court martials in the host country in order to allow victims to attend the proceedings. ${ }^{81}$ In the event that neither of these are possible, the Secretary-General alternatively requested that member states livestream any proceedings so that victims can witness the process. ${ }^{82}$

78 Parsons and Bergin, above n 72, at 182.

79 Campbell, above n 71 , at 705.

80 Smith, above n 32, at 406-407.

81 Special measures for protection from sexual exploitation and abuse: a new approach-Report of the Secretary General, above n 2, at 10 and 15.

82 At 15. 
These kinds of changes would increase the opportunity for victims to experience the cathartic nonlegal accountability that is outlined above. If victims had the opportunity to attend the trial of the peacekeeper who perpetrated the abuse, they would be able to face their abuser and confront them with the reality of their offending. Whether this occurs in the host country at an onsite court martial, or in the troop-contributing country as a result of a disbursement from the Trust Fund is largely irrelevant - the potential positive effect is still the same. Beyond the potential benefits of allowing victims to attend and participate in a trial, onsite courts martial would also improve access to evidence, as well as increasing transparency and legitimacy more generally, by allowing communities where abuse has occurred to see first-hand some form of accountability process being followed. ${ }^{83}$ The live streaming of proceedings may not provide victims with the same level of participation in the process or opportunity to face their abuser as attendance at a trial might provide, but it ultimately still allows the victim to see their abuser being subjected to some form of accountability process. This would ultimately be an improvement on the status quo, where alleged perpetrators are removed from the host country and the victim is potentially left guessing as to the outcome of the allegation.

These changes ultimately rely on the consent of member states, and there is little indication to suggest that this will occur. The reframing of the Trust Fund's disbursement criteria would require General Assembly approval, and the Secretary-General is unable to force member states to hold onsite courts martial, or to provide for the live streaming of proceedings. The Zeid Report made a recommendation for the use of onsite courts martial in 2005, but there has been limited action by troop-contributing countries to hold such proceedings since that recommendation was made. ${ }^{84}$ Although some states have opted to carry out onsite courts martial, these are often rushed and do not provide adequate access for victims or UN officials; for example, at a Pakistani onsite court martial in Haiti in 2012, no external observers were permitted to attend the hearing. ${ }^{85}$

Even if victims cannot attend trials themselves, encouraging troop-contributing countries to mandate the incorporation of victim impact statements into proceedings could be a small improvement that would provide some level of direct accountability to victims. Although active participation in any proceedings is linked to greater positive impacts in terms of recovery, written victim impact statements still provide a valuable opportunity for victims to express their experiences to their abuser. ${ }^{86}$ If troop-contributing countries are unwilling to hold onsite courts martial, and member states refuse to reframe the Trust Fund to provide victims with funding to attend trials, victim impact statements are a possible alternative. Victim impact statements can serve as a vehicle of

83 At 37.

84 A comprehensive strategy to eliminate future sexual exploitation and abuse in United Nations peacekeeping operations, above n 38 , at 10 .

85 Paisley Dodds "UN peacekeepers in Haiti implicated in child sex ring" The Independent (online ed, London, 14 April 2017).

86 Parsons and Bergin, above n 72, at 185-186. 
empowerment, offering victims a chance to have their voices heard even if they cannot actively participate in the proceedings themselves. ${ }^{87}$ If the victims of sexual exploitation and abuse perpetrated by peacekeepers were able to prepare victim impact statements that were then presented at trial, there would be a degree of direct accountability to the victim - although the victim may not have the opportunity to look their abuser in the eye, they would still be able to share their experience and, at least in theory, make their abuser aware of the effects of their offending. This would enhance direct accountability to the victim and aid in their recovery from the abuse by providing a "therapeutic experience ... [with] cathartic effect". ${ }^{88}$ As the UN is subject to budgetary constraints and member states may be apprehensive to bear the costs associated with onsite courts martial or funding victims' attendance at trials, providing for victim impact statements is a cost-effective alternative that still recognises the rights of victims and creates greater direct accountability to them.

\section{The Victims' Rights Advocate and Restorative Justice}

The role of the VRA could be expanded to further encourage adherence to minimum standards and procedural safeguards to ensure timely and genuine proceedings when they do occur. Not only do criminal justice proceedings occur far from the site of the offending, but troop-contributing countries have complete control over their processes. A key part of the VRA's role is engaging with member states, including on the progress of proceedings. ${ }^{89}$ Assessing whether proceedings have adequately catered for the rights and interests of victims could be a way to encourage troopcontributing countries to incorporate mechanisms such as victim impact statements. When coupled with the proposed changes to withhold payments in instances when troop-contributing countries fail to complete or carry out investigations in a timely manner, this expanded role for the VRA and her team of field-based advocates would likely encourage troop-contributing countries to cater for the rights of victims. Ensuring that perpetrators are not simply rushed through proceedings designed to discharge the expectation on troop-contributing countries to investigate is important if victims are going to be incorporated more meaningfully into the accountability process.

Restorative justice processes are becoming more common responses in some countries to incidents of sexual exploitation and abuse. ${ }^{90}$ The nuanced benefits and potential shortcomings of restorative justice are beyond the scope of this article, but it is possible that the use of some form of restorative justice could better cater for the rights and interests of victims and provide them with increased direct non-legal accountability. The potential value of restorative justice processes lies in the opportunity for victims to confront their abuser, participate in the process, share their experiences

87 Edna Erez "Who's Afraid of the Big Bad Victim? Victim Impact Statement as Victim Empowerment and Enhancement of Justice" [1999] Crim LR 545 at 551.

88 At 552.

89 United Nations "Terms of Reference", above n 52, at 2.

90 Campbell, above n 71, at 706. 
and have the abuser accept responsibility in a controlled environment which minimises the potential for further victimisation. ${ }^{91}$ Most restorative justice processes place the victim at the centre of the process, and involve mediated dialogue between the abuser and their victim. ${ }^{92}$

Although conventional restorative justice processes seen in Western countries may not be directly applicable to instances of sexual exploitation and abuse by peacekeepers, incorporating elements of restorative justice into the mechanisms which address these offences could be useful. Many of the opportunities for victims to confront their abusers outlined above rely on the troop-contributing country carrying out some form of trial or judicial process which a victim could participate in, through mechanisms such as victim impact statements. However, restorative justice processes would not require there to have been any exercise of criminal jurisdiction by the troop-contributing country, or an international judicial body. If following an OIOS investigation that substantiated any allegations against a peacekeeper the VRA was able to facilitate a restorative justice process, willing victims would have the opportunity to receive some level of the non-legal accountability that comes with confronting their abuser. Moreover, a controlled and mediated restorative justice process could also help to reduce some of the risks to the victim's well-being caused by pursuing legal accountability.

This may be an unconventional option, but in light of the current arrangement in relation to criminal jurisdiction such a mechanism may be best placed to increase direct accountability to victims through moral retribution and a sense of personal justice that is difficult to acquire through a trial in a foreign judicial system. Troop-contributing countries would not be required to give up their exclusive criminal jurisdiction, peacekeepers would not suddenly be liable for conviction before a foreign body and because the process would not be a legal one carried out by the host country, concerns around minimum standards should not be as prevalent. The VRA and her team of field-based advocates would be well placed to facilitate such a process and the mechanism itself would be relatively low cost, with a potentially high benefit for the victims involved. Providing this forum could also allow for the affected community's trust to be restored in the UN, which would have additional ongoing positive effects.

\section{Further Changes to the Trust Fund}

The Trust Fund is specifically framed to provide assistance and support for victims of sexual exploitation and abuse, but not compensation. ${ }^{93}$ If the Trust Fund was reframed to allow for compensatory payments out of its funds, direct accountability to the victim themselves would be greatly enhanced. Compensation is a clear acknowledgment that harm has been suffered, and that there should be some remedy for that fact. For victims, compensation is formal recognition, often by

91 Campbell, above n 71, at 706; and Parsons and Bergin, above n 72, at 186.

92 Parsons and Bergin, above n 72, at 186.

93 "Trust Fund on Victim Assistance", above n 41. 
a "person in a position of power" that they are owed justice for what has happened to them, and the granting of compensation can therefore have a therapeutic effect. ${ }^{94}$ Practically, the service gaps filled by the Trust Fund are the very services that victims could use compensatory payments to cover regardless, provided that they were available in their community. In this sense, compensation itself would offer a largely therapeutic benefit, and not necessarily any great practical difference to the services already offered. Adequate safeguards could be put in place to prevent compensatory payments from being used irresponsibly or taken advantage of, while still allowing for the exercise of individual autonomy by the victim - something that was infringed through their abuse and exploitation.

Because the Trust Fund includes payments that have been withheld in substantiated instances of sexual exploitation and abuse, compensatory disbursements could provide an increased sense of direct non-legal accountability for victims because their abusers have contributed to the formal acknowledgement of their suffering. This could give a tangible sense of retribution and consequences having been suffered directly to the victim. Compensation is one of the minimum standards outlined in the Declaration of Basic Principles of Justice for Victims of Crime and Abuse of Power. In it, member states are encouraged to first ensure compensation is available from the offender, and in cases when it is not, provide financial compensation themselves for "victims who have sustained significant bodily injury or impairment of physical or mental health as a result of serious crimes". ${ }^{95}$ This aspect is clearly missing from the UN's response to incidents of sexual exploitation and abuse at present. In order to fulfil this standard which is expected of member states, the UN should be able to use the Trust Fund to provide direct accountability to victims in the form of compensatory payments.

\section{CONCLUSION}

Ultimately, until individual member states decide to take action to tackle sexual exploitation and abuse by UN peacekeepers, the unfortunate reality is that these abhorrent offences are likely to continue. Secretaries-General can issue as many reports and make as many recommendations as they want, but the fact remains that under the SOFAs troop-contributing countries retain exclusive jurisdiction over their troops. This poses a significant barrier to legal accountability, and moreover, the hierarchical accountability which the UN can exercise only extends so far. Many of the mechanisms that have been implemented in recent years have been focused on attempting to force troop-contributing countries to investigate allegations and hold perpetrators to account, such as the withholding of payments in substantiated allegations and the transfer of these to the Trust Fund. Additionally, there has been an increasing trend in recent reports by Secretaries-General for measures to instead be framed towards providing for the rights and interests of victims. In this sense, a different

94 Bruce Feldthusen, Olena Hankivsky and Lorraine Greaves "Therapeutic Consequences of Civil Actions for Damages and Compensation Claims by Victims of Sexual Abuse" (2000) 12 CJWL 66 at 75-76.

95 Declaration of Basic Principles of Justice for Victims of Crime and Abuse of Power, above n 3, at [12a]. 
form of accountability can be achieved - non-legal accountability, directly to the victim themselves. Although mechanisms such as the VRA have been a positive step towards this, there are a number of further improvements that could be made, such as the attendance of victims at trials, the incorporation of victim rights statements, the introduction of restorative justice mechanisms and the granting of compensation from the Trust Fund. Unfortunately, these mechanisms are not the solution to the problem of sexual exploitation and abuse being committed by peacekeepers. Instead, they focus on holding those who do commit these crimes to account after the fact. Ultimately, these mechanisms are the UN doing as much as it can in the political reality in which it operates. Every mechanism which provides some form of accountability to innocent civilians who have suffered at the hands of those who were meant to be protecting them is beneficial. 